Cahiers $d u$ MONDE RUSSE

\section{Cahiers du monde russe}

Russie - Empire russe - Union soviétique et États indépendants

$51 / 2-3 \mid 2010$

Dynamiques sociales et classifications juridiques dans l'Empire russe

\title{
Creating a Creole Estate in early nineteenth- century Russian America
}

La création d'un ordre créole : la compagnie russe d'Amérique et sa vision d'une nouvelle civilisation russe dans l'Amérique russe du début du XIXe siècle

\section{Susan Smith-Peter}

\section{(2) OpenEdition}

\section{Journals}

Electronic version

URL: https://journals.openedition.org/monderusse/9198

DOI: $10.4000 /$ monderusse. 9198

ISSN: $1777-5388$

\section{Publisher}

Éditions de l'EHESS

\section{Printed version}

Date of publication: 9 September 2010

Number of pages: 441-459

ISBN: 978-2-7132-2315-0

ISSN: $1252-6576$

\section{Electronic reference}

Susan Smith-Peter, "Creating a Creole Estate in early nineteenth-century Russian America", Cahiers du monde russe [Online], 51/2-3 | 2010, Online since 26 October 2013, connection on 03 September 2022. URL: http://journals.openedition.org/monderusse/9198 ; DOI: https://doi.org/10.4000/ monderusse.9198

This text was automatically generated on 3 September 2022 


\title{
Creating a Creole Estate in early nineteenth-century Russian America
}

\author{
La création d'un ordre créole : la compagnie russe d'Amérique et sa vision d'une \\ nouvelle civilisation russe dans l'Amérique russe du début du XIX siècle
}

\section{Susan Smith-Peter}

On February 4, 1816, the Main Board of the Russian-American Company (RAC) ordered the return to Russian America of the creole Kondratii Ivanovich Burtsov and the creole woman Matrëna Semënovna Kuznetsova, who had both been sent to St. Petersburg for schooling. Due to the length of the journey, they stated that Burtsov, 26, and Kuznetsova, 17, should marry: "And so that the maiden will not return here alone, with their mutual agreement they are being united in matrimony and from its side the Company is providing them, as is decent, with all that is necessary in terms of clothes, shoes and so on." ${ }^{1}$ This seems like less of a concession to the feelings of the young pair than an order motivated by the needs of the company. ${ }^{2}$ This was typical of the RAC's attitude toward creoles, who were the offspring of Russian men and native women living in Russian America and were given the status of a separate estate in 1821. The Company saw them as a group that would be trained to serve the RAC both in their work and in their family life by having children who would be future employees, thus increasing the population in Russian America and spreading the Russian way of life.

Burtsov studied shipbuilding at the Okhta Admiralty wharf on funds provided by the government and the RAC, while Kuznetsova learned how to run a Russian home in the family of the manager of the RAC's main office in St. Petersburg, Ivan Osipovich Zelenskii. According to the comments of the Main Office of the RAC in the January 1818 proposal to create the creole estate, Kuznetsova, while in St. Petersburg, "learned all that is necessary for domestic life: she is able to bake bread, make kvass [a mildly alcoholic drink made of bread], cook cabbage soup (shchi), wash clothes, clean and iron, embroider in a hoop and by hand, also to sew clothes and in addition knows how to read and write." ${ }^{3}$ Upon their return to Novo-Arkhangel'sk (now Sitka, Alaska), Burtsov was to become a senior ship's carpenter, for which he would receive the not inconsequential salary of 1000 rubles a year, with the promise of 200 more for good work. ${ }^{4}$ In contrast, in 1818, the 
promyshlenniki, or Russian subjects working for the Company, agreed to a salary of 300 rubles a year, while artisans were to receive a minimum of 400; both were to receive a monthly ration of flour as well. ${ }^{5}$ Thus, Burtsov would receive more than three times as much as a common worker, suggesting the high value the RAC put on the newly trained creoles.

3 A set of instructions from the Main Office to chief manager of the colonies Aleksandr Andreevich Baranov dated March 22, 1817, stated that "you will have in [Burtsov] a new, and hopefully an educated, citizen who may become an example to others." ${ }^{6}$ The 1816 document noted that Kuznetsova was to "supervise and teach young and orphaned creole girls like her and, if she is successful in this, then in measure with [her successes] do not omit to give her a special reward if possible."7 In 1817, the Main Office asked Baranov, "If the wife of the priest who has been sent to you is able to provide education in household management even to only a few orphaned creole girls, and if perhaps Matrëna Burtsova can also do this, please build a schoolhouse for these women and help them as much as you can. It would be desirable to assign several young females from among the kaiurs [native slaves for the Russians] to assist them." ${ }^{8}$ Burtsov and his wife were to serve as models of a new Russian civilization in Russian America, one that was orderly, monogamous and productive. Rather than relying upon promyshlenniki, the RAC saw creoles as the potential bearers of Russian culture and values.

This article argues that the government created the creole estate for two main reasons: to form a non-taxable estate to serve the RAC rather than the state and as object and subject of Russianization (obrusenie). Ilya Vinkovetsky states that Russianization is different from the later, more aggressive Russification, and consisted of making natives "more like the Russians in specific characteristics that mattered to Russian colonial and ecclesiastical authorities." While Vinkovetsky focuses on the Russianization of the natives, in this article I look at the larger scope of the Russianization plan for creoles, who were both under the control of the RAC and expected to act as models of a stable, productive Russian way of life to both the natives and promyshlenniki.

Given the fact that when the Russian government dealt with the lower orders, it usually focused on extraction of services and taxes rather than on transformation, it is striking that in the case of the creoles, the choice was made not to extract, but to transform. The Russian term kreol was derived from the Spanish criollo, but rather than referring to native-born Europeans, in the Russian context it meant mixed offspring. ${ }^{10}$ According to Lydia Black, the first mention of creoles in a published source comes from Vasilii Mikhailovich Golovnin, who noted in 1822 that, "Following the example of Europeans who hold colonies in West Indies, the company calls those born of Russians and Aleut or American women creoles." ${ }^{11}$ Since the Ibero-American world was the origin point for the term creole, it is telling that the Russians were among those picking up the concept, even though the creole experience in Russian America has not been integrated into the larger literature on creoles and creolization. ${ }^{12}$ Lydia Black notes that the first use she found of the term was in the Novo-Arkhangel'sk (Sitka) parish records in $1816 .{ }^{13}$ Ilya Vinkovetsky has found the term used by one of the founders of the RAC, Nikolai Rezanov, in 1805 in documents held by the Archive of Foreign Politics of the Russian Empire (AVPRI). ${ }^{14}$ Rezanov was a believer in establishing a Western-style empire in the Pacific for Russia and the RAC; his exploits in attempting to open up California and Japan to Russian trade and political influence are well documented. ${ }^{15}$ This suggests that the use of the term 
probably originated from the center and was part of a larger vision of a new overseas Russian Empire.

6 Since the 1990s, there has been an increasing amount of work on creoles in Alaska, which has generally been divided into the study of the experiences of creoles and study of the broader, often impersonal, imperial and national structures affecting creoles' lives. Included in the first group are anthropologists who have attempted to reconstruct the lived experience of creoles of specific tribes. ${ }^{16}$ Since creoles were active as priests and teachers of Russian and native-language schools, which were widespread during the Russian period, many historians have dealt with creoles in the history of education and Orthodoxy in Russian America. ${ }^{17}$ Other works have outlined the positive contributions of the creoles to the development of Russian America. ${ }^{18}$ The experience of Russians and creoles after 1867 has also attracted attention. ${ }^{19}$ Although creole women were crucially important as mediators between Russians and Natives, historians have just started to look at their experiences.$^{20}$ Works on the broader social structures of Russia and America have tended to look at the legal framework for the creole estate and ideas about the identity of creoles. ${ }^{21}$ This article builds upon the works on the structural history of the creoles, which has not traced the events leading to the proposal for a new estate.

7 Archival materials as well as the works of Kirill Timofeevich Khlebnikov, who was manager of the Novo-Arkhangel'sk office of the RAC from 1818 to 1832, allow us to trace the origin and early development of the creole estate during the 1810 s and 1820 s. Khlebnikov's extensive published and unpublished notes influenced policy making within the RAC, all the more as he was manager of the company office from 1834 and one of its directors from $1835 .{ }^{22}$

Although 1821 may seem late for the creation of an estate, Gregory Freeze has shown that the concept of a legally defined system of estates (sosloviia, plural, soslovie, singular) began to take shape in the first decade of the nineteenth century, and that the townspeople and the nobility were the most clearly defined groups. ${ }^{23}$ Freeze notes that "the estate system was dynamic and still actively developing (not disintegrating) in the nineteenth century. ${ }^{24}$ There were four main social conditions (sostoianiia), with many estates in each one..$^{25}$ In this way, the creation of a separate creole estate was not an anomaly but part of a larger common practice.

The system was not entirely the work of the state, as estate members often attempted to limit incomers in order to restrict competition for their privileges. As Freeze notes, the "strong hereditary patterns, the persisting legal distinctions, the segregation of groups in administration and law, the deeply rooted cultural differences among various groups, and the conscious effort of the state to preserve the soslovie separation - all acted to maintain the old social structure even in the face of far-reaching social and economic change." ${ }^{26}$ The creole estate provides a fascinating example of the persistence of such an identity marker even after the estate categories were replaced by racial ones after the sale to the United States in 1867. Observers have noted the continued use of the term creole as a form of identification up until the late twentieth century, even within the very different society of the United States. ${ }^{27}$ 


\section{The Origins of the Creole Estate: Skilled Workers or Non-Taxable Savages?}

10 The creation of the creole estate was in part due to the unique conditions in Russian America, which were different from those in Siberia. Russia's drive eastward is usually seen as starting with Ivan the Terrible's 1552 conquest of the Khanate of Kazan. Russians went east through Siberia and in 1648 Semën Dezhnëv made the quickly forgotten discovery of the Bering Strait. In 1728, explorer Vitus Bering rediscovered the strait that bears his name. Soon, Siberian fur traders began to flood into what became known as Russian America, causing revolt among the Aleuts (now known as the Unangan), the first natives the Russians encountered. ${ }^{28}$

Several trading companies were established, but conflict between them as well as court politics led to the creation of a monopolistic company, the RAC, in $1799 .{ }^{29} \mathrm{RAC}$ founder Grigorii Ivanovich Shelikhov established a Russian settlement on Kodiak Island in 1784 and hired Aleksandr Baranov as its chief manager in 1790. Baranov expanded Russian domination and in 1808 designated Novo-Arkhangel'sk, today's Sitka, located to the east of Kodiak, as the new capital of Russian America. ${ }^{30}$ Baranov encouraged the training of creoles and even had a legitimate creole son and daughter himself with a native woman. ${ }^{31}$ In 1818, Baranov was relieved of duty and replaced with a naval officer. From then until 1867 , naval officers managed the colony. ${ }^{32}$

Part of the reason for the establishment of the creole estate had to do with the lack of agricultural land in Russian America, which meant that Russian peasants could not settle there and continue their old way of life, as they could in Siberia. Instead, hunting furbearing animals formed the main occupation, and Russians were not as skilled as native hunters, whom the Russians forced to hunt for them..$^{33}$ Skilled workers, not peasants, were needed, including navigators, captains, cartographers, and the like, but such Russians were unlikely to move to distant Russian America. An educated creole estate could provide the answer, as its members would be suited to the climate and to Russian ways, the Company believed.

13 This is made clear in an opinion of the Council and Main Office of the RAC dated November 6, 1818, which stated that promyshlenniki should be hired "with good qualities and who know arts or crafts, so that at such a distance they might be an example for the islanders [natives] and useful for them and the Company, but one meets such people extremely rarely, not even enough to fill the places of those who have left [...] and this happens because good people and artisans find work and sustenance at home and do not seek them in a distant country and do not expose themselves to the dangers of the sea and other events. This lack of Russian people in the colonies can be made up by the above-mentioned creoles, raised and educated at the expense and effort of the Company [...] The council considers it useful to leave them as free citizens of those places where they were born, allowing them to work in company posts or in their own households." ${ }_{34}$

Even more plainly, Nikolai Rezanov wrote that "most of the men who come here are depraved, drunk, violent and corrupted to such an extent that any society should consider it a great relief to get rid of them. Here hardships and work make them behave more quietly, and there are few opportunities to get drunk. Returning to Okhotsk they resume the old life again and in a few weeks spend on drink and debauch the products of four years' labor." ${ }^{35}$ 

the Siberian authorities for the Company to pay the taxes for children of certain Irkutsk peasants serving as promyshlenniki. In response, the RAC reactivated earlier plans for a new estate that would be tax exempt. In the pre-reform system, peasants and townspeople were taxable, while other "higher" estates were not. The conflict began when the children of three Russian peasants from Irkutsk province, Kondratii Glazunov, Semën Krylatskii, and Makar Seleznev and baptized Native women (called Americans, or Amerikanki, in the documents), were listed in the seventh census, prompting the Minister of Finance, who at that time was D.A. Gur'ev, to query the Irkutsk governor about the payment of taxes on their behalf. ${ }^{42}$ "Americans" here meant indigenous people who were not Aleuts, including several of the peoples on the mainland. RAC demanding payment of the taxes. The order noted that the Main Office of the RAC had argued that the creoles were not under the control of the Irkutsk authorities, no matter their paternity, as "not one of those born from a Russian has been taken from the islands and left in Russia, and they cannot be taken for physical reasons, as they are not able to bear the change in climate and new food." ${ }^{43}$ The Irkutsk authorities replied that the climate in Irkutsk province "is not significantly different from the climate in the places where the creoles were born," and that "it would be completely against the natural and civil law to allow the return trip to Russia of promyshlenniki while denying them their wives and children, and thus to separate them from husbands and fathers." ${ }_{44}$ 
Thus, while the RAC saw Russian America as separate from the Russian Empire both by climate and tax code, the Siberian authorities saw it as an extension of that empire.

The lack of clear regulations on creoles not only distressed the Irkutsk authorities but also caused problems for creoles. Instructions from the Main Office of the RAC to Baranov, dated March 22, 1817, noted that Andrei Khmanov, who had completed a university course in navigation and was working "in Okhotsk on the Finlandia, and by order of the Okhotsk office is receiving a salary of 1200 rubles. He appears to be working well. Consequently the Main Administration will attempt to secure the rank of officer for him. However, he was very foolish in Okhotsk. For some reason he asked to be assigned to some position and be issued a passport. This was refused by the Company administration. Inform all creoles not to worry about their rank. They will have rank under the special laws drawn up for them." ${ }^{45}$ This gives a sense of the strange position of the creoles. Outwardly in a desirable position with a good salary, the creole Khmanov suffered from lack of a clear rank within the extremely rank-conscious Russian society of the time. When he attempted to clarify the situation, he was refused and here is described as acting foolishly, although his motivations seem reasonable enough. These issues also seem to have been concerning other creoles, as the administration specifically asked Baranov to tell creoles not to worry about rank.

Siberian authorities, as well as creoles, were concerned about what the future might bring. According to the Irkutsk governor-general, the RAC had threatened to petition the emperor "about creoles born in America from unwed Americans [Natives] and about granting [them] citizenship there." 46 The governor-general was eager to prevent this, arguing that legally, children were counted in the estate of their father, not in a different estate. As the fathers of the creoles were peasants and thus taxable, to include the creoles in a tax-exempt group would mean the disappearance of taxpayers from the province's rolls. Instead, he argued that the RAC should have to pay the taxes for the creoles immediately and accurately. ${ }^{47}$

The reference to citizenship dealt with a plan of Nikolai Rezanov, who was sent in 1803 on the first Russian round-the-world voyage to inspect the colonies and act as Russian ambassador to Japan. Minister of Commerce N.P. Rumiantsev gave Rezanov instructions that he was to "provide [the RAC] with plans applicable to that region, administer courts and punishments as much as possible, remove all burdens from the inhabitants, lay firm foundations for every good order." 48 Rezanov was by most accounts a prickly and difficult person, but one with a great deal of energy, part of which he channeled into the making of plans. One of them dealt with the creoles, but Rezanov died in 1807 before it could be presented to the emperor. According to a January 15, 1818 report from the Main Office of the RAC to Minister of the Interior O.P. Kozodavlev,

Rezanov proposed, after his return here, to propose to the government that creoles be made use of for the good of the fatherland and the Company in such a way, so that all of them who are capable of being military men would make up a company garrison for the defense of the ports and fortresses there. And for this several of them would be called to Russia and be taught various forms of service at the front, the beating of drums and so on, while those with other abilities be used for navigation, for written work or for trade and whatever forms of artisanship are needed there, or for the cultivation of the land and in this way create a proper colonial citizenship (sobstvenno kolonial'noe grazhdanstvo), which might be paid by salaries from the Company for the fulfillment of duties in it or by workmanship or by the profits from their works in agriculture, but due to his untimely end, this project was not presented to the government. ${ }^{49}$ 
Citizenship in early nineteenth-century Russia had a different meaning than it does today; as Sergei Pushkarov notes, in contemporary Russian it means "citizen in general," while at that time it referred to "certain categories of the urban population." ${ }^{50}$ In 1821, the creoles would be included in the townspeople estate (meshchanstvo), which was one of those categories Pushkarev mentions. It should not be confused with the later category of colonial citizen, which included promyshlenniki who could no longer work but wished to remain in America. ${ }^{51}$

In practice, Rezanov's idea of colonial citizenship meant that a class of people would be created whose duty and purpose was to serve the company, not to pay taxes to the government. Rezanov's original proposal envisioned the promyshlenniki at the center of a new agricultural society in a Russian America in which they would legally have permanent residence and would be assisted by creoles, but this proposal was rejected by the State Council in 1808 due to fears, not only that tax revenue would be lost, but also that the permanent residents of Russian America would place excessive burdens on peasants in their original communes, as they would no longer perform rural duties (zemskie povinnosti), such as the upkeep of roads, nor would they provide recruits for the army. ${ }^{52}$ As a result, the Company turned to the creoles as an alternative tax-exempt group. It is still not completely clear why there was such a lag between Rezanov's death and the proposal itself, but it seems that these issues of taxation pressed the company to make the attempt again.

25 In its January 1818 proposal, the Company argued both that the creoles should not be taxed because they belonged to the non-taxable savage condition of their mothers and that they were an educated estate above that of their peasant fathers and therefore should not be taxed. The report stated that, even if taxes were levied against the creoles, the latter "will not be in the condition to pay for them, as, aside from fur production, carried out by the Russian-American Company, there are no other means for them to make a living and they do not have money for the payment of taxes, and therefore should revert to that savage condition (dikoe sostoianie), in which were their mothers and the fathers of their mothers, from whom, along with all Aleuts, Catherine the Great ordered not to collect taxes." Later, the document noted that the creoles "are free people through their mothers." ${ }^{53}$ Again, the freedom here was not from the demands of the Company (quite to the contrary), but from the taxes of the state.

The same proposal also emphasized the role of the Company in educating the creoles, stating that the company's predecessor under G.I. Shelikhov established a school in 1785, soon after a permanent Russian settlement was established on Kodiak. At present, the document stated, the RAC provided "schools for study by creoles of the male sex of the Russian language, God's law, arithmetic and navigation. This last is usually taught by one of the navigators in the service of the company, for which they are given a special salary, and other subjects are taught by the promyshlenniki, whoever has the abilities for this, and also receive a special reward for these activities." ${ }^{44}$ Girls were also taught "various handicrafts and works necessary for domestic life, under the surveillance of Russian female overseers. This position was first occupied by titular councilor Banner ${ }^{55}$, but after her death the post was to have been occupied by the request of the administration of the Company by the wife of the priest resident there, to be helped by the creole woman sent there in the past year who married the creole Burtsev, who was sent there with the title of senior ship's carpenter." ${ }^{56}$ 

K T. Khlebnikov wrote in the 1830s: "Only one officer manager, Bander [II. Banner], was married to a Russian woman (rossiianke), - as a result, it was impossible to even think about the education of the female sex. The spouse of Bander (Natal'ia Petrovna) herself headed a foundling home for girls in the [last] two years of her life. After her death this institution dissolved." ${ }^{57}$ This is particularly interesting, given that there is a significant discrepancy in the endowment for this institution given in the published version of the January 15, 1818 report compared to a copy made for the RAC's files. While the recently published version, which was delivered to the Ministry of Internal Affairs, stated that the capital for the girls' schools as well as for orphans and other charitable institutions on Kodiak and Sitka was 25,178 rubles 63 kopecks, the internal document said the capital for these institutions was around 371 rubles..$^{58}$ This money was raised "from the division of a half percent from each ruble, given to stockholders in profits under the division of profits defined by the general meeting of stockholders," but it may well be that it was not actually reaching the intended destination. ${ }^{59}$ According to Ferdinand Petrovich Wrangell, the chief manager of the colonies from 1830 to 1835, prior Chief Manager Matvei Ivanovich Murav'ëv asked the RAC in 1821 for their support in educating orphan girls, but no teacher was found and a girls' school opened only in $1839 .{ }^{60}$ Company and a defeat for the Ministry of Finance and the Siberian authorities, as it classified creoles as tax exempt. The text reads: "Creoles, while in the Colonies, will not be subject to state taxation or state service of any kind unless new regulations will be issued in this matter." ${ }^{61}$ This suggests that the government was willing to devolve some of its functions to the RAC, including its core function of taxation, in order to underwrite the colonization of these lands without significant governmental expenditures. This underlines the difference between Russian America and continental Russia, as the government showed little interest in allowing private companies to take over core state functions in Siberia or elsewhere. The creoles themselves were an estate existing only in the colonies.

The 1821 charter to the RAC provided the legal structure for the creole estate. It stated: "Creoles are Russian subjects. As such, they have a right to governmental protection on the same basis as all subjects belonging to the burgher estate, provided that they have not acquired through personal achievement or other exceptional circumstances membership in another [higher] estate." ${ }^{62}$ The burgher or townspeople estate is expressed as meshchanstvo in the Russian language, which is from the Polish miezczane and was originally applied to town residents in Southern and Western Rus. In the seventeenth century, it was applied to the residents of the meshchanskaia sloboda or trading suburb, who were skilled workers, traders and others..$^{63}$ The estate's composition was ambiguous, including both petty and great merchants organized into merchant and artisan guilds, as well as "merchants, shopkeepers, petty traders, hawkers of secondhand goods, artisans, transport and factory workers, casual laborers, and domestic servants." ${ }^{64}$ Only in 1775 and 1785 did merchants receive privileges separate from the townspeople. ${ }^{65}$ Catherine the Great's 1785 Charter to the Towns "not only confirmed but significantly expanded" the personal rights of the townspeople and "established the principle that the corporate rights granted to townspeople were inalienable and could be taken away only for conviction of a major crime by a court." ${ }^{66}$ Prominent among these rights was the right to own property, which "made them economically independent of the state; and 
their enhanced property rights encouraged them to accumulate property without fear of its arbitrary confiscation by the state." ${ }^{67}$ This in turn gave them economic leverage to influence state policy. Although the state restricted the right to own serfs to the nobility, repeated court cases and prohibitions suggest that non-nobles were buying serfs regardless. ${ }^{68}$ At the same time, the state used the category of townspeople "as a repository for unattached individuals, such as retired soldiers, vagrants, orphans, foundlings, and persons of illegitimate birth, regardless or whether they possessed sufficient capital or an appropriate occupation." ${ }_{69}$

The 1821 statute emphasized the privileged condition of the creole estate. They were taxexempt and not subject to state service. Education was an important part of the creole estate and it linked the creoles to the RAC. The statute noted:

Creoles educated in Russia at the institutions of higher learning at Company expense and who, upon graduation, have achieved the status of students or physicians with all the rights and privileges granted by universities and academies, may not refuse a sojourn of not less than ten years' duration, to serve the inhabitants of that region for an appropriate salary and subsistence allowance provided by the Company. After the completion of such term, they have the right to leave the colonies, if they so wish, and practice their profession elsewhere. ${ }^{70}$

This reinforces the view that creoles were needed as skilled workers and professionals, not as peasants or a downtrodden class. Legally, if creoles only attained a degree below that of the university, they did not have to work for the company. However, if they wanted to return to the colonies, the company was the main and often only employer, so it would have been difficult to avoid.

The list of creoles in the 1818 report, which was based on a census of creoles in Kodiak and Sitka in July 1816, emphasized their educated status, which bolstered the argument for classification as a tax-exempt group..$^{71}$ For example, 27-year-old Kondratii Burtsov, who we met at the beginning of this paper, had "learned Russian language, God's law, geography, history, shipbuilding, the foundations of mathematics and the copying of plans." He was "presently located at the Sitka wharf as a senior ship's carpenter." ${ }^{2}$ His wife, Matrëna Burtsova, now 17, knew how "to read, write, God's law and women's handicrafts." Antipatr Aleksandrovich Baranov, the legitimate son of the RAC's chief manager in the colonies, Aleksandr Baranov, with a native woman, was 20 years old and "[knew] how to read, write, mathematics, some English; was used on various expeditions as a supercargo." ${ }^{33}$ His 13-year-old sister, Irina Aleksandrovna Baranova, had learned "the Russian language, God's law and women's handicrafts." ${ }^{74}$ Similarly, I.I. Banner, who had been the only one of the office managers married to a Russian woman, married a creole after his first wife's death. His sons from that marriage, Ivan, 7 years of age, and Aleksandr, 5 years of age, were in the first class of the Kodiak school. The list of creoles noted that they were the legitimate sons of the titular councilor and late head of the Kodiak office and that they were nobles. They, along with creole boys, were "studying Russian language and God's law." 75

The educational status of the creoles was also emphasized in a decree sent to the chief manager of the colonies, M.I. Murav'ëv, by the Board of Directors, dated February 28, 1822. "The administration of the Company directs you to take note of the fact," the decree stated, "at all times and in all places, that creoles born of legal marriages who are left without a father, as well as those born of a non-legalized union, are without exception to be educated at the Company's expense, wherever and however possible." 76 We can see the similarity in status between legitimate and illegitimate children and the 
responsibility of the company to provide for their education. In contrast, the company had no responsibility to provide for the education of their promyshlenniki. As Lydia Black notes, "No wonder then that the creoles were resented by Russians of lower estates, and their just pride in their status and achievements provoked resentment directed at 'upstarts' on the part of visiting Russians of higher ranks."

However, the position of the creoles was contradictory. While they were superior to Russian workers in some ways, such as their education and estate status, they were often paid less money. Creoles' lives were also highly regimented from an earlier age than was the case with the promyshlenniki who contracted out to the company as adults, and they received lower salaries. The same February 28,1822 decree notes that until creoles reach the age of 16, "they should be given the same support as apprentices now have or will have; from 16 to 20 years of age, they should be assigned according to their abilities to various occupations and by the quality of their work, supply them with pay (soderzhanie) proper to the place they occupy; from 20 to 29 years of age, while also occupying positions according to their capabilities and quality of work, provide them with a salary (zhalovan'e) according to their industriousness and zeal for service." 78

In a salary list from the late 1810s, creoles and Aleuts received between 60 and 150 rubles a year, while creole apprentices received between 180 and 450 rubles a year. ${ }^{79}$ This may reflect the social stratification of creoles, with a skilled subsection receiving more than the others, including many promyshlenniki, whose salary, according to Khlebnikov, began at 350 rubles a year. ${ }^{80}$ Ludwig von Hagemeister, who was head of the colonies from January to October 1818, ordered that since creoles' salaries were inadequate, they should also receive sailors' clothing, two pairs of shoes and one kamlei (a native gut-skin outer garment). ${ }^{81}$ This hybrid outfit may have been similar to a creole uniform and also shows the low pay of most creoles.

This is also much lower than the salaries given Burtsov and Khmanov noted above, at 1,000 and 1,200 rubles, respectively. In the same salary list, Burtsov is listed as receiving 1,000 rubles, in a separate section with three navigators receiving between 2,000 and 2,450 rubles a year, so Burtsov was literally in a different category. ${ }^{82}$ Khlebnikov was dissatisfied with Burtsov's work, it seems, and in addition was concerned to avoid mixing of different groups - a theme which we find throughout his work. It may be that creating a new estate provoked anxiety and a desire to fix the position of the different estates. Khlebnikov argued against sending creoles to St. Petersburg, stating, "There are many examples of persons who studied shipbuilding [in St. Petersburg] and returned without understanding either theory or the practical application of the science, and because of that they are of no use." 83

Of those creoles in the list from 1816, only Burtsov had been educated in shipbuilding, so it is likely that this refers to him specifically. M.I. Murav'ëv also stated that Burtsov was an incompetent worker. ${ }^{84}$

However, other creoles learned their craft better yet picked up unspecified bad habits, according to Khlebnikov: "Some of the pupils learned navigation quite well, but at the same time they acquired a taste for luxuries and learned bad habits. Young people are always guided by example. In a small group dominated by one individual, who, with a paternal attitude supervises the conduct of each and every one, there cannot be so many open vices and evil tendencies as might occur in a large city. Here such sins as thievery and deceit cannot be hidden, and the guilty person is found out right away. But it is not apparent to someone who goes into a worldly city how transgressions are found out and 
punished. As a result, such transgressions are rare here. There used to be some persons here who were steeped in vice; but we would not tolerate such sins, and so in time they completely abandoned their inclinations and became useful citizens." 85

Khlebnikov believed that creoles should remain a separate group, staying in Russian America, and not intermarrying with Russians or going to Russia. In particular, he was opposed to Russian men marrying creole women, writing that "it would be a good thing, and helpful toward increasing population, if a prohibition were instituted against Russians marrying creole women and taking them to Russia, where they experience the change of climate and do not live long, or where they are abandoned by their husbands and are miserable. It would be very desirable to tie this estate with bonds of marriage and homemaking; only in this way can permanent citizens be created." 86

In about 1825, Khlebnikov restated his belief that Russian men should not marry creole women. He stated, "At a suitable age [creoles] must be married to creoles or Aleuts. Although this should be done at their choice, it should be seen to that persons of great difference in age should not be united, that healthy people should not be mixed with those infected with an illness or who are subjects to fits, beauty with ugliness, stupidity with cleverness, or depravity with mildness and modesty." ${ }^{87}$ Making it even clearer that promyshlenniki were seen as unfit to marry creoles, Khlebnikov stated that they should be denied permission to marry creole women, who, upon returning to Russia, "suffer poverty due to impoverished conditions and dissipation of their husbands. In addition the colonies are deprived of inhabitants." Khlebnikov suggested that, "If this prohibition cannot be made on the basis of general government laws, then the local authorities can refuse to sanction such ties for various reasons (pretexts), such as the obligations of employees, their behavior, health, etc." 88

41 Forbidding Russian men to marry creoles would also help to increase the permanent population of Russian America, as we see here that Khlebnikov is especially concerned at the position of creole women in Russia. Not only would their position there be shaky, but they would no longer be capable of increasing the population in the colonies, which was a key interest of the RAC. There was also a strong economic motivation for the company to prevent Russian men from marrying creole women, as such marriages would make the men more likely to remain in Russian America in their old age and to become a burden on the company, as we see in an official decree, approved by Emperor Nicholas I on April 2, 1835, which "sanctioned the establishment in the colonies of permanent settlers from the Russian lower class and peasants who were married to Creoles or Natives and because of advanced years, bad health, and lack of close relatives in Russia decided to remain in America." ${ }^{99}$

They were to become farmers, and the company was responsible for setting them up in a place chosen by the RAC, which would have required expenditures. The decree stipulated: "The Company must build adequate living quarters for them and supply them with the necessary equipment for hunting and farming, and with livestock, domestic fowl and seed grain. It must also provide them with provisions adequate for one year, and further, the Company must see to it that these persons are not in want in the future." ${ }^{90}$ The decree also stated that creoles who left company service and wished to become farmers would also receive the same assistance. Thus, it would have been in the interest of the RAC to have everyone in service rather than be farmers.

43 Khlebnikov also felt that the creoles should remain separate from native society, partly in order to provide a model of monogamous domesticity he found sadly lacking in 
native customs. Khlebnikov, writing probably in 1825 , stated that the company should provide aid to "establish them at the main factory [Pavlovskaia Harbor] with houses and vegetable gardens. Do not settle them among Aleuts in their habitations." ${ }^{11}$ In 1822, Chief Administrator of the colonies M.I. Murav'ëv wrote that the Company should "not allow them to return to a savage condition. They must be concerned and use all the resources at their disposal to ensure that the creoles who have become familiar with a European way of life will not fall away from it. Those who have some ability and inclination to perform household work or agriculture or gardening should receive every assistance from the Company. Married persons with children should be given preference." ${ }^{92}$ This concern with retaining the Russian way of life of the creoles derived from earlier experiences with creoles resettled to Fort Ross, who, according to Murav'ëv in 1823, once they had "obtained freedom they very soon gave up European clothing and clothed themselves with bird parkas, made themselves baidarkas, and in a word returned to their primitive state." ${ }^{93}$

Khlebnikov saw the spread of monogamy among creoles as a means of preserving their civilized identity as well as a way of gradually changing certain customs of the Aleuts, which he identified as savage. In 1825 he wrote: "The Aleuts should not be alienated from their native habits and customs, but nevertheless efforts should be made to educate them regarding their characters and physical fitness, to eradicate laziness and harmful habits, such as a woman having several husbands or a man having several concubines and especially the unnatural usage of sodomy. A settled way of life and domesticity may help a little to gradually accustom them to work and tidiness, while supervision and attention of the authorities may keep them from depravity." ${ }^{44}$

Such domesticity was to extend to Russian-style agricultural practices as well. Khlebnikov noted in 1825 that the company should get creoles interested in husbandry by giving "them cattle on the condition that they are able to get hay for them with their own effort, but they cannot keep more than two milk cows and one bull. The surplus calves are to be given to the company at set prices, and they should give a written promise that they will not sell animals on the side or kill any for their own use until the number of animals is increased to local requirements." Such measures would of course benefit the company more than the creoles by providing the RAC with extra meat, which was often hard to come by and expensive. Similarly, he notes, "With assistance from the company give them the opportunity to breed pigs, goats and chickens." Khlebnikov saw animal husbandry as part of a civilizing process, writing, "These measures are necessary because people who do not care about husbandry, or the dissolute, are capable of squandering all of their own and that of others to satisfy their inclinations." ${ }^{95}$

As the company often stated, the creoles were free citizens of those places where they were born. However, this meant their enrollment not in a system of universal rights, but in the system of estates as townspeople rather than peasants. Creole women were crucial to the creation of this new world, as the wives and mothers of its monogamous family units. As an added benefit to the RAC, the creoles were tax exempt and thus saved the company a considerable amount of money.

In the writings of Khlebnikov and of other RAC officials, we see a pattern in which Russians were seen as insufficiently civilized to carry out the Russianization of Russian America. That task, they argued, should be taken up by the creoles. The main means of doing this was through the creation of a society of married creole couples, who would provide the example of monogamous, orderly life in contrast to the disorder of both the 
promyshlenniki and the natives. Ironically, this point of view devalued the culture of both pre-existing groups and defined the Russian way of life as productive and stable, traits which would suit the needs of the Russian-American Company, which the creole estate was created to serve.

\section{NOTES}

1. N.N. Bolkhovitinov, et al., eds., Rossiisko-Amerikanskaia kompaniia $i$ izuchenie Tikhookeanskogo severa, 1815-1841: Sbornik dokumentov (M.: Nauka, 2005), 16.

2. Cf. Gwenn A. Miller, Kodiak Kreol: Communities of Empire in Early Russian America (Ithaca: Cornell University Press, 2010), 131-132.

3. AVPRI (Arkhiv vneshnei politiki Rossiiskoi imperii), f. Rossiiskaia amerikanskaia kompaniia (RAK), op. 888, d. 251, 1. 33ob-34.

4. Bolkhovitinov, Rossiisko-Amerikanskaia, 17.

5. Winston L. Sarafian, “Alaska's First Russian Settlers," The Alaska Journal 7, 3 (Summer 1977): 176.

6. Basil Dmytryshyn, E.A.P. Crownhart-Vaughan and Thomas Vaughan, eds., The Russian American Colonies, 1798-1867, vol. 3 (Portland: Oregon Historical Society, 1989), 244. Burtsov was presented to Alexander I in 1810, at which time the tsar asked "why were the four Americans who studied here before not presented at the conclusion of their studies?" As a result, Minister of Internal Affairs O.P. Kozodavlev attempted to present Burtsov to the tsar before the latter was sent to Russian America. RGVIA (Rossiiskii gosudarstvennyi voenno-istoricheskii arkhiv), f. 35, Kantseliariia nachal'nika Glavnogo shtaba Ego Imperatorskogo Velichestva. op. 5, tom 1, d. 290, Delo po otnosheniiu Ministra Vnutrennikh Del ob otpravlenii v Kolonii Amerikanskoi Kompanii Kreola Burtsova, 26 fevralia 1817 g., 1. 2. Although Burtsov was denied an audience with the emperor, this exchange shows that Alexander took an interest in the creoles sent to St. Petersburg and at one time was curious to see the result of their education. I would like to thank Aleksandr Orlov for bringing this material to my attention.

7. Bolkhovitinov, Rossiisko-Amerikanskaia, 17. Burtsov and Kuznetsova were indeed married in 1817 and returned to the colonies, where Burtsov worked at the NovoArkhangelsk wharf until 1828, when he was transferred to Kodiak with his family. He and his wife had three children: Ivan (b. ca. 1818), Dmitrii (b. 1821) and Mariia (1825-1828). A.V. Grinëv, Kto est' kto $v$ istorii russkoi Ameriki (M.: Academia, 2009), 82.

8. Dmytryshyn and Crownhart-Vaughan, Russian American Colonies, 245. Hieromonk Gedeon, in his notes on a stay in Kodiak in 1804, stated that kaiurs were "Aleuts who are taken from various settlements at the will of the company for work in various artels and at the harbor. At the order of the baidarshchik [head of a work crew], they erect about the middle of March weirs on streams for the fish catch, construct labazy [fish drying racks], and begin seining in the localities where there are fish appearing in the bays[...] The kaiurs chop wood and transport it by hand from nearby localities, by baidaras from 
distant ones. They also cut hay. In the fall, they are dispersed to the odinochki [small forts] to trap foxes for the company; in winter, they deliver food supplies to the headquarters or to the Harbor," etc. Lydia Black, trans. and ed., The Round-the-World Voyage of Hieromonk Gideon, 1803-1809 (Kingston: The Limestone Press, 1989), 61-62. While Alaskan scholars have argued that kaiurs were workers, Russian scholars term them slaves. See Andrei V. Grinëv, "The Kaiury: The Slaves of Russian America," Alaska History 15, 2 (Fall 2000): 1-18.

9. Ilya Vinkovetsky, Russian America: An Overseas Colony of a Continental Empire, 1804-1867 (Oxford: Oxford University Press, 2011), 96.

10. Lydia T. Black, “Creoles in Russian America," Pacifica 2, 2 (Nov. 1990): 142.

11. Ibid., 143.

12. Ralph Bauer and José Antonio Mazzotti, eds., Creole Subjects in the Colonial Americas: Empires, Texts, Identities (Chapel Hill: University of North Carolina Press, 2009).

13. Lydia Black, Russians in Alaska, 1732-1867 (Fairbanks: University of Alaska Press, 2004), 215.

14. Ilya Vinkovetsky, "Circumnavigation, Empire, Modernity, Race: The Impact of Round-the-world Voyages on Russia's Imperial Consciousness," Ab Imperio, no. 1-2 (2001): 201.

15. N.N. Bolkhovitinov, "N.P. Rezanov i pervoe krugosvetnoe plavanie rossiian (1803-1806)," in Istoriia russkoi Ameriki, 1732-1867, t. 2: Deiatel'nost' Rossiisko-Amerikanskoi kompanii, 1799-1825, Idem, ed. (M.: Mezhdunarodnye otnosheniia, 1999), 84-114.

16. E.S. Piterskaia, “Kreoly Aliaski $\mathrm{v}$ svete protsessov mezhkul'turnogo vzaimodeistviia," Etnograficheskoe obozrenie, no. 6 (2007): 94-104; Sergei Kan, Memory Eternal: Tlingit Culture and Russian Orthodox Christianity through Two Centuries (Seattle: University of Washington Press, 1999).

17. Lydia Black, trans., The Journals of Iakov Netsvetov: The Atkha Years, 1828-1844 (Kingston: The Limestone Press, 1980); Idem, The Journals of Iakov Netsvetov: The Yukon Years, 1845-1863 (Kingston: The Limestone Press, 1984); E.A. Okladnikova, "Science and Education in Russian America," in S. Frederick Starr, ed., Russia's American Colony (Durham: Duke University Press, 1987), 218-248; Richard Dauenhauer, Conflicting Visions in Alaskan Education (Fairbanks: University of Alaska Press, 1997); Metropolitan Kliment (Kapalin), Russkaia Pravoslavnaia Tserkov' na Aliaske do 1917 goda (M.: OLMA Media Group, 2009); Antoinette Shalkop, "The Russian Orthodox Church in Alaska," in Starr, Russia's American Colony, 196-217.

18. Black, "Creoles in Russian America"; Svetlana G. Fëdorova, The Russian Population in Alaska and California, late eighteenth century-1867 (Kingston: The Limestone Press, 1973), 206-274; Michael Oleksa, "The Creoles and their Contributions to the Development of Alaska," in Barbara Sweetland Smith and Redmond J. Barnett, eds., Russian America: The Forgotten Frontier (Tacoma: Washington State Historical Society, 1990), 185-195.

19. S.G. Fëdorova "Russkoe nasledie v sud'bakh korennogo naseleniia Aliaski," in I.S. Gurvich et al., eds., Traditsionnye kul'tury Severnoi Sibiri i Severnoi Ameriki (M.: Nauka, 1981), 244-266; S.A. Korsun, "Russkoe nasledie na Aliaske" Kunstkamera, no. 13 (2003): 57-69.

20. Gwenn A. Miller, “'The Perfect Mistress of Russian Economy': Sighting the Intimate on a Colonial Alaskan Terrain, 1784-1821," in Ann Laura Stoler, ed., Haunted by Empire: 
Geographies of Intimacy in North American History (Durham: Duke University Press, 2006), 297-322; Miller, Kodiak Kreol.

21. Black, Russians, 209-220; Vinkovetsky, "Circumnavigation, Empire," 191-210; Sonja Luehrmann, Alutiiq Villages under Russian and U.S. Rule (Fairbanks: University of Alaska Press, 2008), especially Chapter 5.

22. K.T. Khlebnikov, Notes on Russian America: Parts II-V: Kad'iak, Unalashka, Atkha, the Pribylovs, translated by Marina Ramsay and edited by Richard Pierce (Kingston: The Limestone Press, 1994), xiv; Grinëv, Kto est' kto, 573.

23. Gregory L. Freeze, "The Soslovie (Estate) Paradigm and Russian Social History," American Historical Review 91, 1 (Feb. 1986):17-18.

24. Ibid., 14.

25. Ibid., 22.

26. Ibid., 36 .

27. Margaret Mary Wood, "The Russian Creoles of Alaska as a Marginal Group," Social Forces 22, 2 (1943): 204-208; S.A. Mousalimas, From Mask to Icon: Transformation in the Arctic (Brookline: Holy Cross Orthodox Press, 2003), 19.

28. N.N. Bolkhovitinov et al., eds., Istoriia russkoi Ameriki, 1732-1867, vol. 1 (M.: Mezhdunarodnye otnosheniia, 1997).

29. Barbara Sweetland Smith and Redmond J. Barnett, "Introduction," in Russian America, 11.

30. Ibid., 11-12.

31. Grinëv, Kto est' $k$ to, 44.

32. Vinkovetsky, "Circumnavigation, Empire, Modernity," 205.

33. Nikolai Bolkhovitinov, "Kontinental'naia kolonizatsiia Sibiri i morskaia kolonizatsiia Aliaski: skhodstvo i razlichie," Acta Slavica Iaponica 20 (2003): 109-125; James Gibson, "Russian Dependence on the Natives of Alaska," in S.W. Haycox and M.C. Mangusso, eds., An Alaska Anthology: Interpreting the Past (Seattle: University of Washington Press, 1996), 21-42.

34. Bolkhovitinov, Rossiisko-amerikanskaia, 50.

35. "Letter, Rezanov to the Directors of the Russian-American Company, from New Archangel, November 6, 1805," in P.A. Tikhmenev, A History of the Russian-American Company, vol. 2: Documents, trans. Dmitri Krenov, ed. Richard A. Pierce and Alton S. Donnelly (Kingston: The Limestone Press, 1979), 160.

36. Andrei Grinëv, "The Watchful Eye of the Empire: Passports and Passport Control in Russian America," Alaska History 23:1-2 (2008): 21-34.

37. Bolkhovitinov, "Vvedenie," Istoriia russkoi, t. 2, 12.

38. A.V. Grinëv, "Russkie kolonii na Aliaske na rubezhe XIX v.," in Ibid., 22.

39. Ibid., 31.

40. Bolkhovitinov, "Vvedenie," 13.

41. Bolkhovitinov, Rossiisko-amerikanskaia, 30. This was taken from a list of creoles in Kodiak and Novo-Arkhangel'sk as of July 1816. AVPRI, f. RAK, op. 888, d. 251, 1. 5ob-25.

42. AVPRI, f. RAK, op. 888, d. 714, 1. 1-1ob. Kondratii Glazunov was an "old voyager" promyshlennik who served in Russian America from 1784 to the early 1820s. His creole son, Andrei Kondrat'evich Glazunov (1800-1846) was a navigator who played an important 
role in the exploration of the Yukon area, taking part in the founding of Mikhailovskii redoubt (now St. Michael) on Norton Sound and founding Ikogmiut (now Russian Mission) on the Yukon in 1836, which he led from 1841 to 1845. See Grinëv, Kto est' kto, 126-127; Richard Pierce, Russian America: A Biographical Dictionary (Kingston: The Limestone Press, 1990), 167-169; James VanStone, "Russian Exploration in Interior Alaska: An Extract from the Journal of Andrei Glazunov," Pacific Northwest Quarterly 50, 2 (1959): 37-47. VanStone terms Glazunov's expedition "one of the great accomplishments in the history of Alaskan exploration." (39). See Grinëv, Kto est' kto, 612. Semën Krylatskii was a Siberian exile and settler (posel'shchik) sent to Russian America in 1794. For an account of his tribulations, see Winston L. Sarafian, "Alaska's First Russian Settlers," The Alaska Journal 7 (1977): 174-177. His creole son, Sergei Semënovich Krylatskii, studied at the Kodiak school and was a clerk in the RAC Okhotsk office with the status of his father that of an Irkutsk peasant. Grinëv, Kto est' kto, 271. Makar Seleznëv was an Irkutsk peasant and employee of RAC from the 1800s and was finally settled as a pensioner of RAC on Afognak Island in the 1840s. Grinëv, Kto est' kto, 480. His creole son, Khristofor Makarovich Seleznëv (1806 - ?) was the head of creole settlements in the Kodiak division, for which he received a salary from the RAC. Grinëv, Kto est' kto, 480. See also AVPRI, f. RAK, op. 888, d. 251, $1.7 \mathrm{ob}, 11 \mathrm{ob}, 12 \mathrm{ob}, 14 \mathrm{ob}$. Thus, the creole sons of these three men all had responsible positions with the Company.

43. AVPRI, f. RAK, op. 888, d. 714, 1. 1 ob.

44. Ibid., 1. 2ob-3.

45. Dmytryshyn and Crownhart-Vaughan, Russian American Colonies, 245.

46. AVPRI, f. RAK, op. 888, d. 714, 1. 2.

47. Ibid., 1. 3ob.

48. "From an Instruction of Nikolai P. Rumiantsev to the Representative of the RussianAmerican Company, Nikolai P. Rezanov," in N.N. Bashkina et al., eds., The United States and Russia: The Beginning of Relations, 1765-1815 (Washington: U.S. Government Printing Office, 1980), 372.

49. Bolkhovitinov, Rossiisko-Amerikanskaia, 29-30.

50. Sergei Pushkarov, comp., George Vernadsky and Ralph Fisher, Jr., eds., Dictionary of Russian Historical Terms from the Eleventh Century to 1917 (New Haven: Yale University Press, 1970), 27.

51. Andrei Grinëv, “'Advanced in Age, Decrepit and Unfit': Colonial Citizens and the Formation of a Permanent Russian Population in Alaska," Alaska History 24, 2 (Fall 2009): 31-60.

52. AVPRI, f. RAK, op. 888, d. 251, 1. 30-31; A.A. Gromyko et al., eds. Vneshniaia politika Rossii XIX i nachala XX veka, ser. 1, vol. 4 (M.: Izdatel'stvo politicheskoi literatury, 1965), 617 , note 168 .

53. Bolkhovitinov, Rossiisko-Amerikanskaia, 30.

54. Ibid.

55. Natal'ia Petrovna Banner (d. 1806) - wife of head of Kodiak officer of the RAC, I.I. Banner (Johan von Banner), whose family was originally from Denmark. Grinëv, Kto est' $k t o, 43$. In Imperial Russia, official documents often referred to women with the rank of their husband. In this case, Johan von Banner was a titular consular, so his wife was also referred to with that rank. 
56. Bolkhovitinov, Rossiisko-Amerikanskaia, 29.

57. R.G. Liapunova and S.G. Fëdorova, comp, Russkaia Amerika v neopublikovannykh zapiskakh K.T. Khlebnikova (Leningrad: Nauka, 1979), 242. My translation. See also Khlebnikov, Notes, 350.

58. Bolkhovitinov, Rossiisko-Amerikanskaia, 29; AVPRI, f. RAK, op. 888, 1818-1819, d. 251, 1. 10 .

59. Bolkhovitinov, Rossiisko-Amerikanskaia, 29.

60. Okladnikova, "Science and Education," 238.

61. Quoted in Black, Russians, 215.

62. Ibid.

63. V.V. Shilkina, V.A. Fedorov, "Meshchane," in V.L. Ianin et al., eds., Otechestvennaia istoriia (M.: Bol'shaia rossiiskaia entsiklopediia, 2000), 3:570.

64. Elise Kimerling Wirtschafter, Social Identity in Imperial Russia (DeKalb: Northern Illinois University Press, 1997), 134.

65. Ibid., 132.

66. Boris Mironov and Ben Eklof, The Social History of Imperial Russia, 1700-1917, vol. 2 (Boulder: Westview Press, 2000), 115.

67. Ibid., 117.

68. Elise Kimerling Wirtschafter, Structures of Society: Imperial Russia's "People of Various Ranks" (DeKalb: Northern Illinois University Press, 1994), 29-30.

69. Wirtschafter, Social Identity, 132.

70. Quoted in Black, Russians in Alaska, 215.

71. AVPRI, f. RAK, op. 888, d. 251, 1. 2ob.

72. Ibid., 1. 5ob.

73. Ibid. A supercargo, according to The American Heritage Dictionary, is "an officer on a merchant ship who has charge of the cargo and its sale and purchase."

74. AVPRI, f. RAK, op. 888, d. 251, 1. 11ob.

75. Ibid., 1. 14ob.

76. Basil Dmytryshyn and E.A.P. Crownhart-Vaughan, trans. and eds., Colonial Russian America: Kyrill T. Khlebnikov's Reports, 1817-1832 (Portland: Oregon Historical Society, 1976), 45.

77. Black, “Creoles," 147.

78. S.G. Fëdorova, ed., Russkaia Amerika v "Zapiskakh" Kirilla Khlebnikova: Novo-Arkhangel 'sk (M.: Nauka, 1985), 99.

79. Ibid., 63.

80. Ibid., 97.

81. Ibid., 69.

82. Ibid., 63.

83. Quoted in Luehrmann, Alutiiq Villages, 143.

84. Grinëv, Kto est' kto, 82 .

85. Dmytryshyn and Crownhart-Vaughan, Colonial Russian America, 49. 
86. Fëdorova, Russkaia Amerika, 104. Translation modified from Dmytryshyn and Crownhart-Vaughan, Colonial Russian America, 49-50.

87. Khlebnikov, Notes on Russian America, 73.

88. Ibid., 71-72.

89. Grinëv, "Advanced in Age," 43-44.

90. Dmytryshyn and Crownhart-Vaughan, Russian American Colonies, 399-400.

91. Khlebnikov, Notes on Russian America, 73.

92. Translation modified from Dmytryshyn and Crownhart-Vaughan, Colonial Russian America, 45. See Bolkhovitinov, Rossiisko-Amerikanskaia, 140, for full document.

93. National Archives, Washington D.C., Records of the Russian-American Company, Records of the Former Russian Agencies, Record Group 261, microfilm roll 22, pp. 224-225. I would like to thank Andrei Grinëv for bringing this source to my attention.

94. Khlebnikov, Notes on Russian America, 74.

95. Ibid., 73-74.

\section{ABSTRACTS}

\section{Abstract}

In Russian America, creoles were the offspring of Russian men and Native women. This article argues that the creation of a creole estate in the early nineteenth century by the RussianAmerican Company (RAC) and the Russian government had two main goals: to create a nontaxable estate that would serve the RAC rather than the state and to spread the Russian way of life. Rather than envisioning Russian workers for the RAC as culture bearers, the RAC and the state expected creoles to bring together experience of local conditions with knowledge of Russian traditions, culture and language, which was fostered by the expectation that all creoles would be educated by the company. Using a wide variety of archival sources from the $1810 \mathrm{~s}$ and 1820 s, the article examines the origin of the creole estate as an attempt to create a new orderly, monogamous, and productive Russian civilization in the New World.

Résumé

En Amérique russe, les créoles étaient le fruit de l'union d'hommes russes et de femmes autochtones. L'article débat sur le fait que la création, au début du XIX siècle, d'un ordre créole par la Compagnie russe d'Amérique (CRA) et le gouvernement russe répondait à deux buts principaux : créer un ordre non imposable qui servirait la CRA plutôt que l'État et étendre le mode de vie russe. Plutôt que d'imaginer les ouvriers russes de la CRA comme des porteurs de culture, la CRA et l'État comptaient sur les créoles pour associer leur expérience des conditions de vie locales à la connaissance des traditions, culture et langue russes, ce qui était favorisé par la perspective que la compagnie se chargerait de l'éducation de tous les créoles. Faisant appel à un très large éventail de sources d'archives des années 1810-1820, l'article étudie l'origine de l'ordre créole comme une tentative de créer dans le Nouveau Monde une nouvelle civilisation russe, ordonnée, monogame et productive. 
AUTHOR

SUSAN SMITH-PETER

College of Staten Island/ CUNY Department of History 